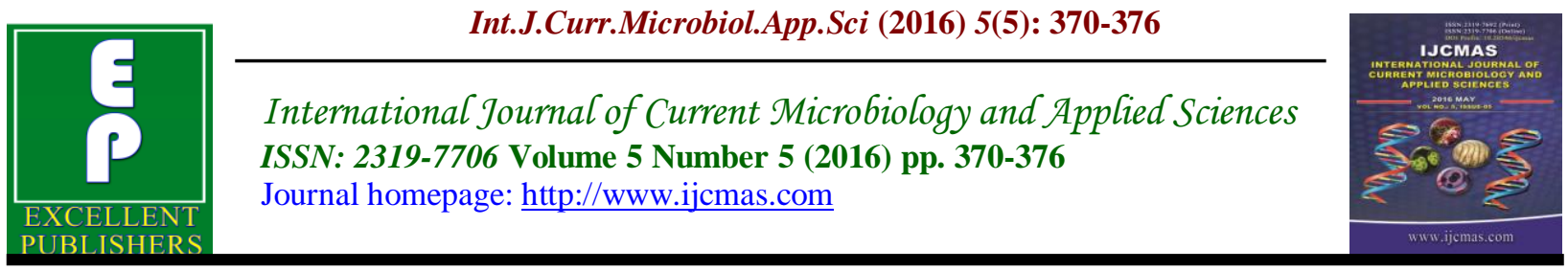

Original Research Article

http://dx.doi.org/10.20546/ijcmas.2016.505.038

\title{
Study of Student's Expectations about the Biochemistry Lecture Handouts at RAK Medical and Health Sciences University
}

\author{
Saidunnisa Begum ${ }^{1}$, B.K. Manjunatha Goud ${ }^{2}$, Jeevan K. Shetty ${ }^{3}$ and Beenish Zaki ${ }^{4}$ \\ ${ }^{1}$ Chairperson and Professor of Biochemistry, Ras Al Khaimah Medical and \\ Health Sciences University, Ras Al Khaimah, U.A.E \\ ${ }^{2}$ Assistant Professor of Biochemistry, Ras Al Khaimah Medical and Health \\ Sciences University, Ras Al Khaimah, U.A.E \\ ${ }^{3}$ Associate Professor of Biochemistry, Ras Al Khaimah Medical and Health \\ Sciences University, Ras Al Khaimah, U.A.E \\ ${ }^{4}$ Former senior instructor of Biochemistry, Ras Al Khaimah Medical and \\ Health Sciences University, Ras Al Khaimah, U.A.E \\ *Corresponding author
}

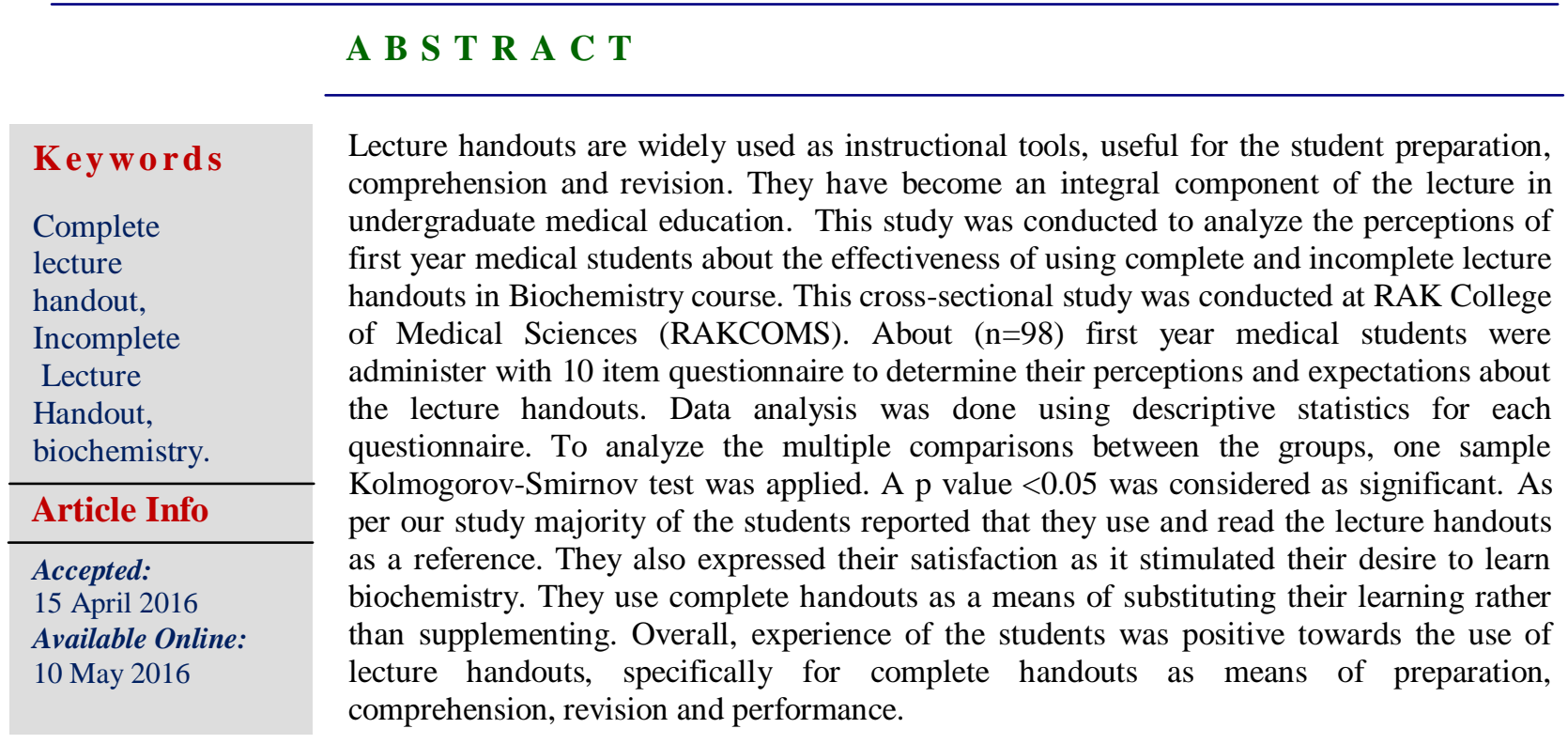

\section{Introduction}

Lecture handouts are widely used as instructional tools. Handouts make the lectures "portable and enduring" (Kroenke, 1991) and helps to improve the recall of information and test performance. It is a common practice to provide PowerPoint presentations and to publish on the website for the students' access. First year medical students are mostly dependent on teacher because of their exposure to a new curriculum in a medical school. Because of this, they have the requirement for the learning resources, especially lecture handouts (Kroenke, 1991). 
It is often necessary to guide them through handouts, as they are not mature enough to manage their time for learning and to look for the right references. (Kroenke, 1991).

A lecture handout can be defined as an instructional tool that complements a lecture resulting in improved understanding of information and test performance (Wayne state university).

There are different formats exists for lecture handouts. The use of a particular format depends on the purpose (Kiewra, et al., 2002).

1. Do you want the students to use the handout as a guide or reference after the lecture?

If the handout is intended as a guide to promote active learning during the lecture, it should be structured in type of handout is called 'incomplete' since students must add their own notes in order to complete the handout.

If the handout is meant to be a reference, it should contain all the information that students need to learn and therefore is called a 'complete' handout. (Kiewra, et al., 2002)

How you want the students to use the handout may depend on one or more of the following factors:

\section{Nature of the Content You are Teaching}

Certain content areas may naturally lend themselves to a specific format. For example, if the content involves a complex pathway, better to provide a complete handout which can be used as a reference (Wayne state university, Bligh, et al., 2000).

\section{Level and/or Characteristics of the Learner Group}

In some circumstances, a learner at an introductory level may require a more complete handout compared to an advanced level learner. Likewise, there may be circumstances where a beginner can learn best by actively participating in the lecture by using an incomplete handout. Perhaps, an advanced learner is at a point of learning the critical information and skills and may need a complete handout (Wayne state university).

\section{Educational Philosophy}

Some educators believe that learning is best achieved through active note taking by the student, whereas others believe learning is best achieved by providing the complete information to the students. Research does not support one philosophy over the other what's important is that one way or another (notes either taken by the student or provided by the instructor), students should have complete and accurate information to review and process after the lecture. (Wayne state university, Bligh, et al., 2000)

\section{Objectives}

Present study was designed to analyze the perceptions of first year medical students about the effectiveness of using complete and incomplete handouts provided to learn Biochemistry.

\section{Methods}

This was a cross-sectional study conducted among the first year medical students $(n=98)$ studying Biochemistry at RAK College of Medical Sciences (RAKCOMS).

At RAKCOMS, classes were conducted using white board and PowerPoint 
presentations (PPT). After the class, lecture handouts (PPT) were uploaded on to the university management system (UMS) for the students' access. Type of the lecture handout may vary from one faculty to other as some of them use complete handouts whereas others use incomplete handouts to teach Biochemistry.

Once lecture handout is prepared and used for teaching it is important to determine its effectiveness. Purpose of the present study was to determine the student's perceptions and expectations with regards to lecture handouts provided to them.

The 10 item survey questionnaire was developed after literature review and discussion with the faculty and staff. Most of the questions were close-ended type. After obtaining permission from the institutional ethics committee, prevalidated survey questionnaire was administered to 98 first year MBBS students.

Data analysis was done separately for each questionnaire using descriptive statistics. For multiple comparisons between the groups, one sample Kolmogorov-Smirnov test was applied. A p value $<0.05$ was considered significant.

\section{Results and Discussion}

Students enrolled were 98 and represented in the study sample. There were 57 (58\%) females and 41 (42\%) males. Majority of the students were $(95.27 \%, \mathrm{p}<0.001)$ using the lecture hand-outs for studying Biochemistry. Many of them were having the opinion (91.75\%, $\mathrm{p}<0.001)$ that lecture handouts were useful for learning Biochemistry.

About $83.0 \%$ of the students $(p<0.001)$ have felt complete lecture handouts were useful in understanding biochemistry topics and also stimulated their desire to learn biochemistry (66.34\%, $\mathrm{p}<0.001)$.

Majority of the students $(75.76 \%, \mathrm{p}<0.001)$ felt that complete lecture handouts helped them to understand the subject and made their learning enjoyable. About $84.0 \%$ of the students $(\mathrm{p}<0.001)$ were having the opinion that complete lecture hand-outs satisfied their quantity of learning in comparison to incomplete handouts. They also opined that (79.21\%, p<0.001) complete lecture handouts were helpful in filling the learning gaps. Almost three fourth of the students $(p<0.001)$ prefer a complete lecture handout over the incomplete handout for understanding of the Biochemistry.

About $64.95 \%(\mathrm{p}<0.001)$ of the study group felt that there should be mix of incomplete and complete lecture handouts for understanding of a particular system and associated clinical conditions. Along with lecture handouts, students were using other resources like text books $(38.16 \%)$ and You Tube (31.58\%) (Tablel-1).

The faculty, who is an academician and content expert, is in the best position to determine how to design the handout to accomplish his or her learning outcomes. (11)

It is important to devote sufficient time for developing lecture handout. A welldeveloped handout augments the lecture and enhances student learning and creates interest in a topic. A poorly developed handout usually results in poor student learning and consequently poor faculty and course evaluations (Better teaching, Frederick, 2002). 
Table.1 Showing the results of students' perception on Lecture handouts

\begin{tabular}{|c|c|c|c|c|c|c|c|}
\hline \multirow[t]{2}{*}{ Demographics: } & \multicolumn{2}{|c|}{$\begin{array}{c}\text { Males } \\
\text { (Total 41) }\end{array}$} & \multicolumn{2}{|c|}{$\begin{array}{l}\text { Females } \\
\text { (Total 57) }\end{array}$} & \multicolumn{2}{|c|}{ Total \% } & \multirow{2}{*}{$\begin{array}{c}\text { One sample } \\
\text { Kolmogorov- } \\
\text { smirnov test }\end{array}$} \\
\hline & Yes & NO & Yes & NO & Yes & NO & \\
\hline \multicolumn{8}{|l|}{ Question } \\
\hline $\begin{array}{l}\text { 1. Do you use faculty lecture hand-outs } \\
\text { for studying Biochemistry }\end{array}$ & 40 & 1 & 53 & 4 & \multicolumn{2}{|c|}{95.27} & 0.001 \\
\hline $\begin{array}{l}\text { 2. Do you think lecture handouts are } \\
\text { useful for learning Biochemistry? }\end{array}$ & 39 & 2 & 50 & 6 & 91.75 & 8.25 & 0.001 \\
\hline \multirow{2}{*}{$\begin{array}{l}\text { 3. In understanding biochemistry topics } \\
\text { which type of lecture handouts were } \\
\text { useful? }\end{array}$} & *CLH & $\begin{array}{l}* * \text { ICL } \\
\mathrm{H}\end{array}$ & CLH & $\begin{array}{l}\text { ICL } \\
\mathrm{H}\end{array}$ & & & \\
\hline & 34 & 8 & 49 & 9 & 83.0 & 17.0 & 0.001 \\
\hline $\begin{array}{l}\text { 4. Which type of lecture handouts } \\
\text { stimulated your desire to learn? }\end{array}$ & 27 & 13 & 40 & 21 & 66.34 & 33.66 & 0.001 \\
\hline $\begin{array}{l}\text { 5. Which type of lecture handouts made } \\
\text { you enjoy understanding the portion } \\
\text { of the Biochemistry course? }\end{array}$ & 30 & 10 & 45 & 14 & 75.76 & 24.24 & 0.001 \\
\hline $\begin{array}{l}\text { 6. Which type of lecture hand-outs } \\
\text { satisfied you with regards to the } \\
\text { quantity of learning experience in } \\
\text { biochemistry? }\end{array}$ & 34 & 7 & 50 & 9 & 84.00 & 16.00 & 0.001 \\
\hline $\begin{array}{l}\text { 7. Which type of lecture handout was } \\
\text { helpful in filling the learning gaps? }\end{array}$ & 32 & 8 & 48 & 13 & 79.21 & 20.79 & 0.001 \\
\hline $\begin{array}{l}\text { 8. You prefer to have which type of } \\
\text { lecture hand-out for understanding } \\
\text { Biochemistry? }\end{array}$ & 31 & 10 & 47 & 14 & 76.47 & 25.53 & 0.001 \\
\hline \multirow{2}{*}{$\begin{array}{l}\text { 9. Do you feel that there should be a } \\
\text { mixture of incomplete and complete } \\
\text { lecture hand-outs for a better } \\
\text { understanding of a particular system } \\
\text { and associated clinical conditions? }\end{array}$} & YES & $\mathrm{NO}$ & YES & $\mathrm{NO}$ & \multirow[t]{2}{*}{64.95} & \multirow[t]{2}{*}{35.05} & \multirow[t]{2}{*}{0.001} \\
\hline & 26 & 14 & 37 & 20 & & & \\
\hline $\begin{array}{l}\text { 10. What are the other resources you use } \\
\text { to study? }\end{array}$ & \multicolumn{2}{|c|}{$\begin{array}{l}\text { Text book } \\
38.16 \%\end{array}$} & \multicolumn{2}{|c|}{$\begin{array}{l}\text { Web sites } \\
19.74 \%\end{array}$} & \multicolumn{2}{|c|}{$\begin{array}{l}\text { You Tube } \\
31.58 \%\end{array}$} & $\begin{array}{l}\text { Any other } \\
10.53 \%\end{array}$ \\
\hline
\end{tabular}

* Complete lecture handout (CLH), ${ }^{* *}$ Incomplete lecture handout (ICLH). 
Example · COMPLETE HANDOUT
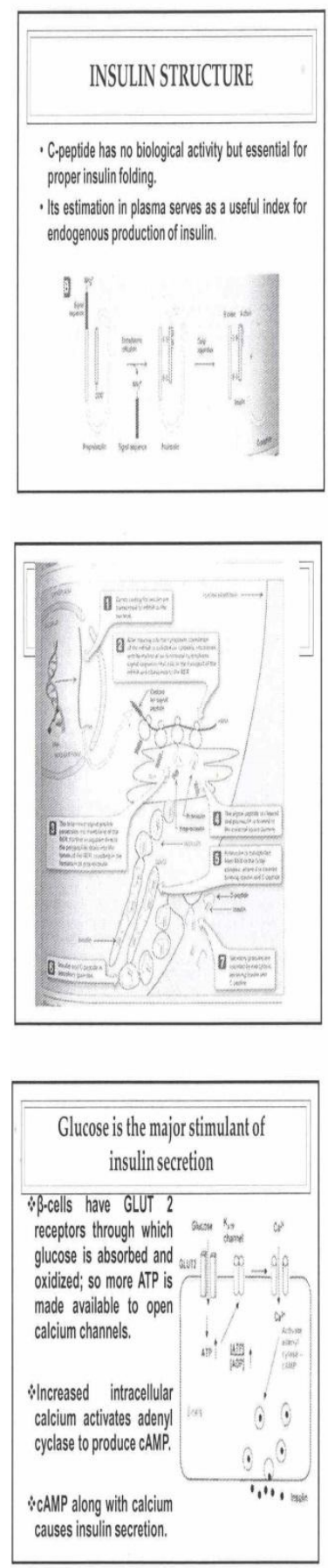

EXample - NCOUPLETE HENDOUT
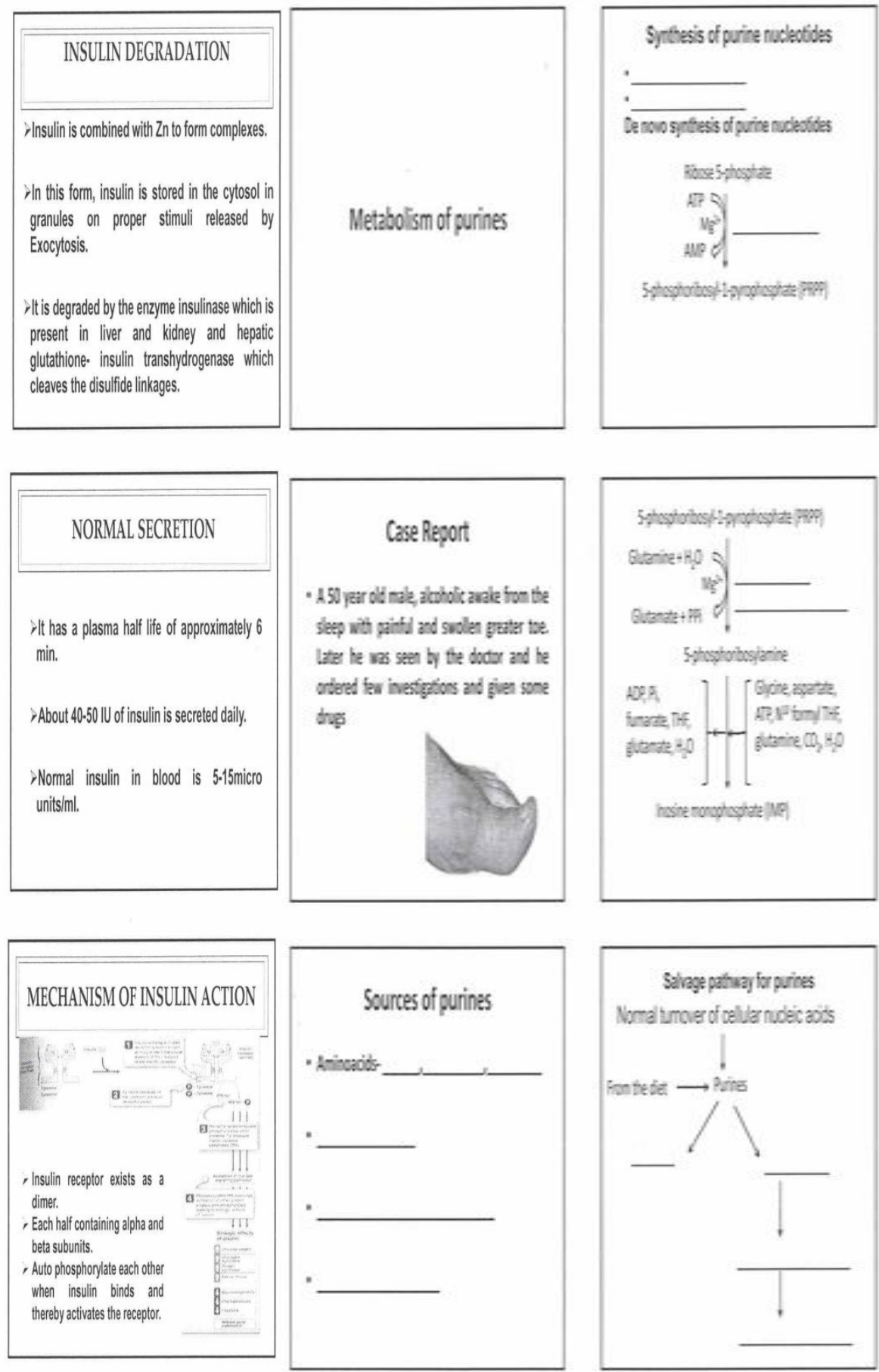

According to Nelson-Wong et al., complete handouts allow students to write less this enables them in listening. This approach is best for courses that include a greater degree of conceptual topics such as Biochemistry. (Nelson-womg, 2000).

In line with previous studies, our study also 
showed the usefulness of complete handouts in learning Biochemistry.

If students are assured of complete lecture presentations they would give their full attention to the lecturer and refer to the presentation later (Joe Varghese 2012).

In case of incomplete handouts, students are required to fill in the missing information through note-taking. This may be best utilized in analytical, problem-based courses such as applied clinical biochemistry (Nelson-wong, 2000).

Cardetti, et al., concluded that incomplete handouts allow the students to follow the lecture attentively from which they can comprehend synthesize and apply the concepts. This could be the reason why some percentage of students in this study preferred incomplete handout (Cardetti, et al., 2010).

The current findings suggest that there may not be a single best practice for handout completeness, and it may vary according to type of course or as per the educational philosophy of the faculty.

Around two third of study group opined that mix of complete and incomplete lecture handouts are better for understanding the concepts with their application. This finding is in line with Murray, (1997), they suggested that creative use of complete and incomplete lecture handouts will satisfy the needs of students' learning by achieving all the learning outcomes.(Murray, 1997)

\section{Final Checklist}

Once you have determined how you want the students to use the handout and which format best accomplishes your learning outcomes, it is important to construct your handout in a professional manner that is useful for students. Using the following guidelines listed below will ensure the development of a high quality educational tool:

1. Always include lecture outcomes 2 . Organize the material in a logical order 3. Use clear and simple language 4. Omit extraneous information 5. If appropriate, include references and review questions 6 . Choose graphics that clearly illustrate the topic 7. Use an easy-to-read font 8. Clearly define all abbreviations 9. Minimize discipline-specific abbreviations, or clearly define them. 10. Proof read for clarity, organization, accuracy, spelling and grammar 11. For complete handouts, explain all technical terms and important information. Include all text and figures that students will need to meet learning outcomes. 12. Make sure all images are labeled. 13. For incomplete handouts, make sure students have the opportunity during the lecture to take notes and document all the important concepts covered during the lecture. Leave plenty of white space so students can add notes. 14. For technology based handouts, ensure the text and all graphics have transitioned legibly to a printed format (Wayne state university).

In conclusion, overall experience of the students was positive towards the use of lecture handouts, specifically for complete handouts as means of preparation, comprehension, revision and performance. Using a mix of lecture handouts (complete and incomplete) helped to meet the expectations of heterogeneous students and could be followed routinely in the classroom. Much care is needed when the educators provide a lecture handout to the students to enhance learning experience.

\section{Acknowledgements}

Our sincere thanks to all the students of first 
year MBBS, of RAK College of Medical Sciences, RAKMHSU for their co operation and support throughout the study. We are thankful to, Dean of RAKCOMS for his continuous support and motivation for conducting this study.

\section{References}

Better Teaching, More Learning: Strategies for Success in Postsecondary Settings. Phoeniz, AZ: Oryx Press.

Bligh, Donald, A. 2000. What's the use of lectures? San Francisco: Jossey-Bass. Davis, James R.

Cardetti, F., Khamsemanan, N., Orgnero, M.C. J. Scholarship of Teaching and Learning, January 2010Vol. 10, No. 1,

Effective teaching behavior in the college classroom." In Raymond P. Perry and John C. Smart. Effective Teaching in Higher Education: Research and Practice (pp. 171-204). New York: Agathon Press.

Frederick, Peter, J. 2002. "Engaging students actively in large lecture settings." In Christine A. Stanley and M. Erin Porter. Engaging Large Lecture Classes. Strategies and
Techniques for College Faculty (pp. 58-66). Bolton, Massachusetts: Anker Publishing Company, Inc.

How to Prepare Lecture Handouts - Wayne State University www.teaching academy.med.wayne.edu/pdf/preparin g_lecture_handouts.

Joe Varghese, Minnie Faith, Molly Jacob. 2012. Impact of e-resources on learning in biochemistry: first-year medical students' perceptions. BMC Medical Education BMC series 201212:21

Kiewra, Kenneth, A. 2002. "How classroom teachers can help students learn and teach them how to learn." Theory into Practice, 41(2): 71-80.

Kroenke, K. 1991. Handouts: making the lecture portable. Med. Teacher, 13: 99-203.

Murray, Harry, G. 1997. "Nine ways to reduce cognitive load in multimedia learning." Educational Psychologist, 38(1): 43-52.

Nelson-Wong, E., Eigsti, H., Hammerich, A., Ellison, August 2013N. J. Scholarship of Teaching and Learning, Vol. 13, No. 3.

\section{How to cite this article:}

Saidunnisa Begum, B.K. Manjunatha Goud, Jeevan K. Shetty and Beenish Zaki. 2016. Study of Student's Expectations about the Biochemistry Lecture Handouts at RAK Medical and Health Sciences University. Int.J.Curr.Microbiol.App.Sci.5(5): 370-376.

doi: http://dx.doi.org/10.20546/ijcmas.2016.505.038 